\title{
Liver Sinusoidal Endothelial Cells and Regulation of Blood Lipoproteins
}

\author{
Dmitri Svistounov ${ }^{1}$, Svetlana N. Zykova ${ }^{1,2}$, Victoria C. Cogger ${ }^{1}$, \\ Alessandra Warren ${ }^{1}$, Aisling C. McMahon", \\ Robin Fraser ${ }^{3}$ and David G. Le Couteur ${ }^{1}$ \\ ${ }^{1}$ Centre for Education and Research on Ageing and ANZAC Research Institute, \\ University of Sydney and Concord RG Hospital, Sydney, \\ 2Department of Nephrology, University Hospital of Northern Norway, Tromsø, \\ ${ }^{3}$ University of Otago, Christchurch, \\ ${ }^{1}$ Australia \\ ${ }^{2}$ Norway \\ ${ }^{3}$ New Zealand
}

\section{Introduction}

Dyslipidaemia is a well-described major independent risk factor for cardiovascular disease (Lin et al.). It is well established that the liver plays the central role in lipid metabolism and liver malfunction is one of the main sources of dyslipidemia (Watson et al., 2003). However, most of the studies so far have focused on the role of hepatocytes in lipid turnover. Indeed, hepatocytes do play a central role in liver lipid metabolism, but they are not alone. Hepatocytes do not have direct contact with the circulation. Any blood-borne lipoprotein particle must first pass through a filter comprised of a layer of endothelial cells, lining the walls of liver sinusoids, before it can contact the liver parenchyma. Likewise, lipoproteins remodelled or synthesized by the liver encounter the same barrier before they reach systemic circulation.

\section{The structure of the hepatic sinusoid}

The hepatic sinusoids are small blood vessels, comparable to capillaries in size, that perfuse the hepatocytes. However, unlike the capillaries in other tissues, sinusoids are formed by a discontinuous endothelium that lacks any significant underlying basement membrane. Walls of sinusoids are formed by the liver sinusoidal endothelial cells (LSECs). LSECs are separated from liver parenchyma by the perisinusoidal extravascular space, known as the space of Disse (Figure 1A). LSECs contribute only 15-20\% of all liver cells but comprise $70 \%$ of the population of sinusoidal cells in the liver (Arias, 1990; Arii and Imamura, 2000; Blouin et al., 1977; Knook and Sleyster, 1976).

The LSECs are perforated by trans-cytoplasmic pores called fenestrae, which do not have any intervening diaphragmatic membrane, and thus are fully patent holes through the cell (Figure 1A-B). This specialized lace-like morphology of the LSECs minimizes any barrier to 
the bi-directional transfer of solutes and particulate substrates between the sinusoidal blood and hepatocytes, whilst retaining the capacity and substantial surface area to undergo interactions with circulating blood cells including immune cells (Cogger and Le Couteur, 2009; Fraser et al., 1995; Wisse et al., 1996). Fenestrae are not uniformly distributed over the LSEC surface but are aggregated into groups of tens to hundreds in gossamer thin areas of cytoplasm and towards the periphery of the cell. These areas of fenestral aggregations are termed sieve plates (Figure 1B). Between $60-75 \%$ of fenestrae are found within sieve plates in rats (Vidal-Vanaclocha and Barbera-Guillem, 1985) but isolated fenestrae are also frequently observed on the LSEC surface.

The LSEC becomes fenestrated at an early gestational stage (Enzan et al., 1997; MartinezHernandez and Amenta, 1993; Nonaka et al., 2007; Smedsrod et al., 2009). The porosity of the sinusoids depends on the number and especially the size or diameter of the fenestrae. The diameter of fenestrae has a normal distribution curve of about 50-200nm (Cogger and Le Couteur, 2009). Gaps larger than about 200nm are regarded as artifacts formed during specimen preparation for electron microscopy (Akinc et al., 2009; Fraser et al., 1978; Fraser et al., 1980; Hilmer et al., 2005a).

Fenestrae have been found in many species including such diverse species as man, rat, mouse, guinea pig, sheep, goat, rabbit, fowl, monkey, baboon, bat, kitten, dog, turtle and fish (Cogger and Le Couteur, 2009).

The fenestrated endothelium was first suggested as a filter of chylomicrons by Wisse in 1970 (Wisse, 1970) from their reported diameters (Fraser et al., 1968) and termed the "liver sieve" once sieving was confirmed (Fraser et al., 1978; Naito and Wisse, 1978). Fenestrae allow the transfer of a wide range of substrates including plasma and plasma molecules, such as plasma proteins, some lipoproteins and colloidal particles (Le Couteur et al., 2005). The latter also include artificial chylomicron-like nanospheres such as Intralipid, but also small viruses leading to hepatitis, viral vectors for DNA manipulation of hepatocytes.

The fenestrated LSEC can be defined as an ultrafiltration system because it is a low pressure system with pores approximately 100nm in diameter. Specifically, the liver sieve can be described as a Loeb-Sourirajan ultrafiltration system, with the LSECs providing the thin porous layer (Baker, 2004). The transfer of fluid across an ultrafiltration system can be calculated using the Hagen Poiseuille equation for ultrafiltration where the flux of fluid is proportional to the number of pores and the radius of the pores to the power of four (Baker, 2004; Le Couteur et al., 2006; Warren et al., 2005). Therefore small changes in the size of fenestrae has profound effects on the size and number of substrates and macromolecules that can gain passage into the space of Disse. Indeed, manipulation of fenestrae diameter might have a role in regulating the transfer of substrates in response to physiological changes, such as feeding and fasting (O'Reilly et al., 2010).

The space of Disse is the extravascular space lying between the hepatocytes and LSECs. It contains some components of extracellular matrix and most components of blood plasma filtered through LSEC's sieve plates. Extracellular matrix in the space of Disse contains fibronectin and collagen type I, III, V, and VI. Collagen type IV is also present but unlike its sheet-like polymeric presentation in typical basement membranes, here it appears in the form of discontinuous aggregates (Martinez-Hernandez and Amenta, 1993). Of note, basement membrane has not been identified in liver sinusoids in any non-pathological state or developmental stage until old age (Enzan et al., 1997; Martinez-Hernandez and Amenta, 1993; Nonaka et al., 2007; Smedsrod et al., 2009), where its appearance is believed to be a sign of age-related degeneration and - possibly - a cause of pathology. 

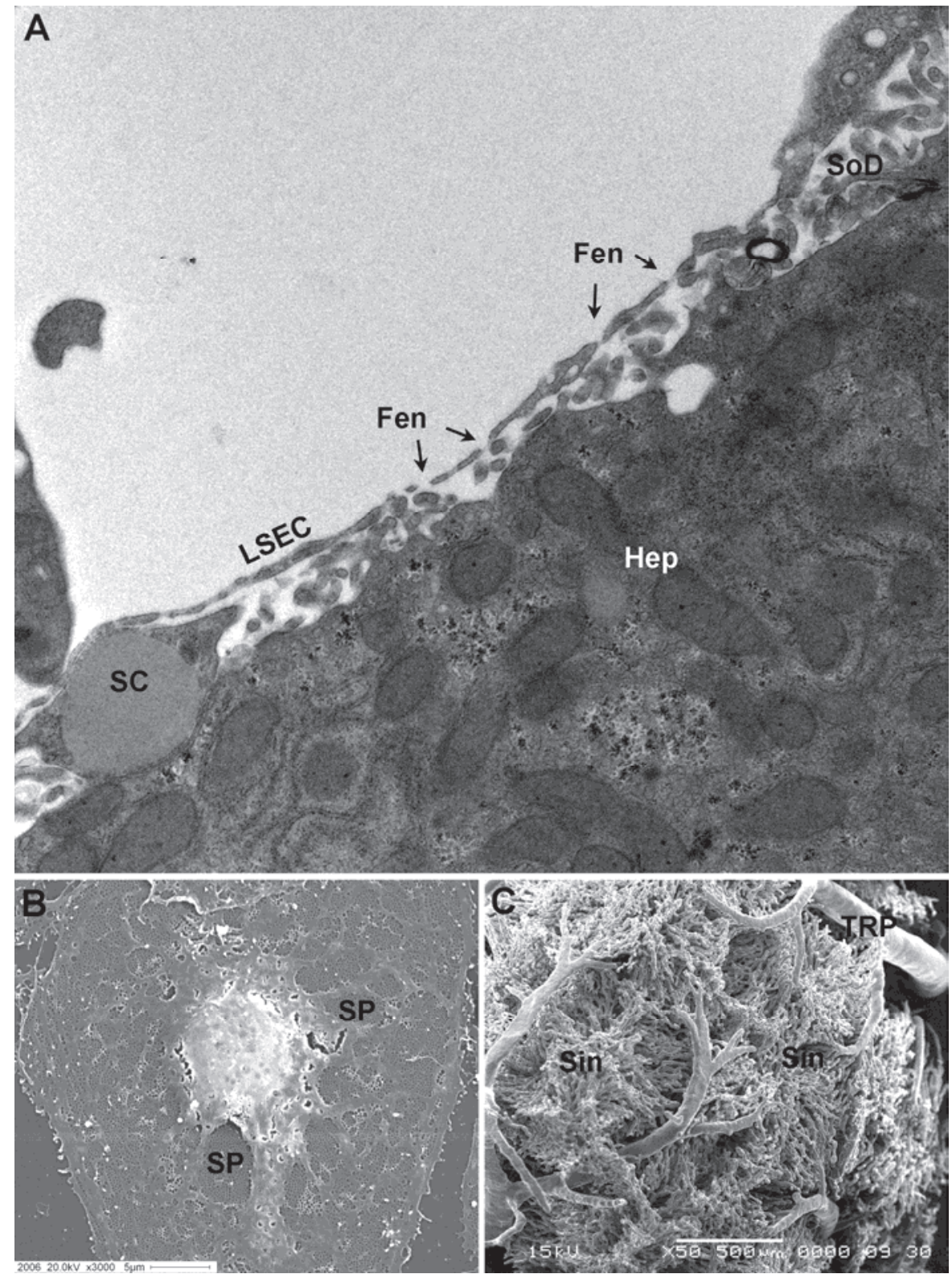

Fig. 1. A: Transmission electron micrograph showing liver sinusoidal endothelial cell (LSEC) perforated by fenestrae (Fen). (Hep) - hepatocyte, (SoD) - space of Disse, (SC) - stellate cells with lipid droplet in space of Disse. B: Scanning electron micrograph of an isolated liver sinusoidal endothelial cell showing fenestrae clustered into sieve plates (SP). C: Scanning electron micrograph of a vascular cast showing branches of the portal vein (TPV) with surrounding sinusoidal network (Sin). (Preparations performed by A Warren). 
Multiple microvilli from the the sinusoidal surface of the hepatocytes protrude into the space of Disse and increase the available surface area for the recognition, transport and diffusion of substrates to and from the liver (Cogger and Le Couteur, 2009; Fraser et al., 1995; Wisse et al., 1996).

There are three other cell types residing in the liver sinusoids apart from the LSECs: Kupffer cells (resident liver macrophages), stellate cells and pit cells. Kupffer cells represent only $20 \%$ of all the population of liver sinusoidal cells but $80-90 \%$ of all tissue macrophages in the body (Knook and Sleyster, 1976). They generally reside within the lumen of the liver sinusoids and take up bacteria and other large particles, such as cell debris, from the circulation by phagocytosis. In response to bacterial infection, Kupffer cells produce cytokines and a number of soluble pro-inflammatory factors that promote influx and activation of neutrophils (Smedsrod et al., 1994; Smedsrod et al., 2009) and may alter the porosity of the sinusoids to promote cirrhosis (Dobbs et al., 1994). Together, LSECs (pinocytosis) and Kupffer cells (phagocytosis) constitute the hepatic reticuloendothelial system (RES), the most powerful scavenger system of mammals and other terrestrial vertebrates (Aschoff, 1924; Kawai et al., 1998).

\section{The normal function of the LSEC in regulation of blood lipids}

Because of the LSECs fenestrae, all lipoproteins except large chylomicrons have unimpeded access to the hepatocytes. After delivering triglycerides to peripheral tissues, chylomicrons become processed into so-called "chylomicron remnants" that carry significant amounts of cholesterol and are highly pro-atherogenic (Fujioka and Ishikawa, 2009; Karpe et al., 1994). At the same time they become small enough to pass through LSECs fenestrae (Fujioka and Ishikawa, 2009) and can be taken up by hepatocytes, which allows liver parenchyma to be the major site for removal of pro-atherogenic chylomicron remnants from the blood (Cooper, 1997; Dietschy et al., 1993) under normal circumstances. However, fast and efficient blood clearance of highly atherogenic chylomicron-remnants by hepatocytes requires well fenestrated LSECs.

\section{Ageing of the LSEC and regulation of blood lipids}

Many important diseases, particularly cardiovascular diseases, that result in disability and death, occur late in life, indicating that aging itself is a key risk factor. Old age is associated with significant changes in the cells of the hepatic sinusoid. Previously, it has been considered that the liver does not undergo significant aging changes because of its large functional reserve, regenerative capacity and dual blood supply (Popper, 1986). Only a few descriptions of the aging liver have been generally established, such as an increase in the number of polyploid and binucleate hepatocytes (Schmucker, 1998) and "brown atrophy", which is a reduction in liver mass accompanied by the deposition of the aging pigment, lipofuscin (Popper, 1986). Today it has become clear that age-related changes in hepatic structure and function are significant and influence systemic exposure to xenobiotics, endogenous substances associated with disease and medications (McLean and Le Couteur, 2004). Thus, such changes in the liver have implications for many diseases of aging and the aging process itself.

It has now been reported that old age is associated with substantial ultrastructural changes in the LSECs and space of Disse in intact livers of the rat (Jamieson et al., 2007; Le Couteur et 
al., 2001), human (McLean et al., 2003), the mouse (Ito et al., 2007; Warren et al., 2005) and the non-human primate, Papio hamadryas (Cogger et al., 2003). The findings have been replicated in at least three separate centres around the world (Furrer et al.; Ito et al., 2007; Le Couteur et al., 2001; Stacchiotti et al., 2008). These changes have been termed 'pseudocapillarization' because the aging sinusoids become similar to capillaries seen in other non-fenestrated vascular beds (Le Couteur et al., 2001). Unlike 'capillarization' seen in the hepatic sinusoid in cirrhosis of the liver, aging is not associated with any of the typical changes apparent on light microscopy, such as bridging fibrosis and nodular regeneration (Le Couteur et al., 2001; Le Couteur et al., 2008). In old age, LSEC thickness is increased by approximately $50 \%$ and there is a similar reduction of about $50 \%$ in the porosity and number of fenestrae (Figure 2). These changes are associated with perisinusoidal basal lamina deposition in many old livers and some scattered collagen in the space of Disse. The effect of aging on the diameter of fenestrae has been inconsistent between species, however there is a trend towards a reduction in diameter of around 5-10\% (Le Couteur et al., 2008). Isolated LSECs typically retain some of these ultrastructural changes. Fenestrae diameter was reduced in old age from $194 \pm 1 \mathrm{~nm}$ to $185 \pm 1 \mathrm{~nm}$ in isolated rat LSECs (O'Reilly et al., 2009).
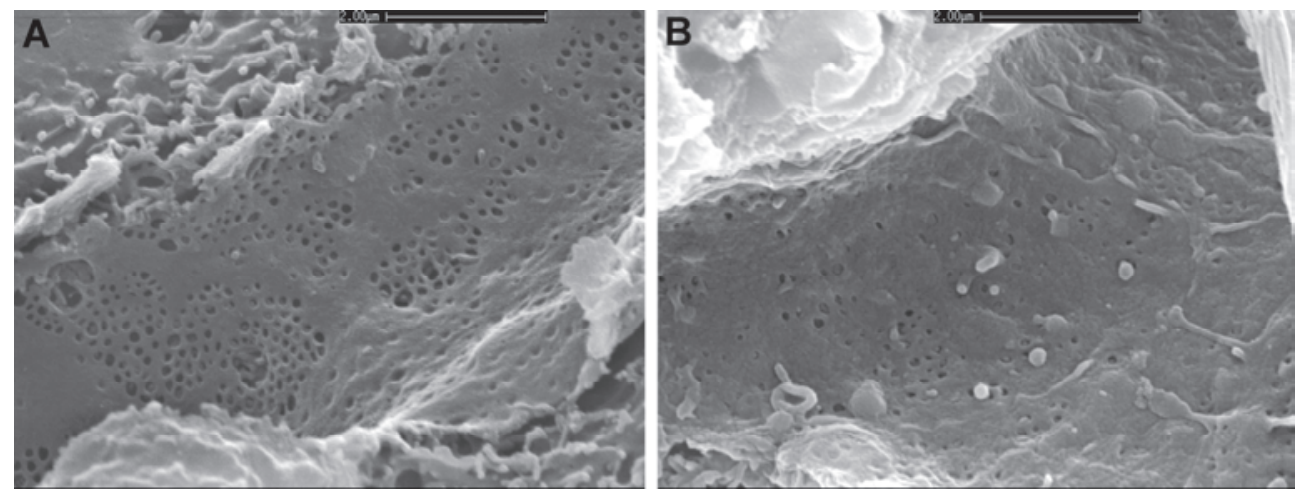

Fig. 2. Scanning electron micrographs of the liver sinusoid of a young (A) and old (B) rat. The loss of fenestrae perforating the endothelial cell surface in the old liver is apparent. (Preparations performed by A Warren).

Fenestrations have a role in the transfer of lipoproteins from blood to the hepatocyte, therefore it is likely that pseudocapillarization of sinusoids will impair lipoprotein clearance by the liver and contribute to dyslipidaemia in older people (Le Couteur et al., 2002). Atherosclerosis increases dramatically with old age and its complications affect most older people (Lakatta and Levy, 2003). The clearance of chylomicron remnants is significantly impaired in older people (Borel et al., 1998; Krasinski et al., 1990) and in those aged 65 years and older, remnant-like lipoprotein cholesterol is associated with the development of coronary artery disease (Simons et al., 2001). To determine whether age-related defenestration impairs the transfer of lipoproteins across the LSECs, the multiple indicator dilution method was used to study lipoprotein disposition in perfused rat livers (Hilmer et al., 2005b). In young livers, lipoproteins (approximately $50 \mathrm{~nm}$ diameter) entered the entire 
extracellular space whereas in old livers, the lipoproteins were confined to the vascular space. These results strongly suggest that age-related pseudocapillarization impairs the hepatic disposition of lipoproteins and thus plays a role in age-related dyslipidaemia.

Matrix heparan sulfate proteoglycans bind and sequester lipoprotein remnants (Williams, 2008). In old age, formation of basal lamina beneath LSECs leads to a change in the proportions of extracellular matrix components and may result in impaired passage of lipoproteins across the space of Disse. However, the importance of this pathway in lipoprotein turnover has not been studied sufficiently, especially in connection to aging.

A reduction in caloric intake by about $40 \%$ increases maximum life expectancy and is associated with a delay in the onset of most age-associated disorders and pathology (Everitt et al., 2005). It has also been demonstrated that caloric restriction delays the onset of pseudocapillarization in rats. In the old caloric restricted rats, endothelial thickness was significantly less and fenestrae porosity was significantly greater than in the old ad libitum fed rats. Moreover, caloric restriction prevented the age-related increase in perisinusoidal collagen IV staining (Jamieson et al., 2007). The finding that caloric restriction influences pseudocapillarization suggests that the latter is secondary to the aging process and thus potentially reversible. As a consequence, modulation of LSEC fenestrations might be a therapeutic target for the treatment of age-related dyslipidemia and prevention of vascular disease. On the other hand, early onset of pseudocapillarization and dyslipidemia occur in a transgenic mouse model of Werner syndrome, a rare premature aging syndrome in humans.

Another hallmark of old age - the reduction in liver size as a fraction of body weight - is usually in the order of 25-35\% (Le Couteur and McLean, 1998) and is associated with a decrease in the number of hepatocytes. In addition, several studies have shown that the total hepatic blood flow is reduced by about 30-50\% (Le Couteur and McLean, 1998). Liver perfusion, which is the blood flow per mass of liver, is also reduced in old age but to a lesser extent than total blood flow. Mechanisms for these changes remain unclear; however, a recent study using high resolution in vivo microscopy has shown how pseudocapillarization might contribute to these phenomena. There was a $14 \%$ reduction in the numbers of perfused sinusoids with old age and a 35\% reduction in sinusoidal blood flow (Ito et al., 2007). Narrower sinusoids with thickened LSECs and swollen stellate cells with abundant lipid droplets were also observed. It was concluded that these changes caused age-related reduction in hepatic perfusion and hepatic blood flow by blocking the sinusoids (Ito et al., 2007). The clearance of highly extracted substrates from the circulation is dependent on blood flow, therefore the age-related reduction in hepatic blood flow has a dramatic effect on the liver's overall function (Le Couteur and McLean, 1998), including the clearance of lipoproteins.

It is reasonable to conclude that pseudocapillarization, in combination with a reduction in hepatic blood flow, are two major factors contributing to age-related dyslipidemia.

\section{Scavenger function of LSEC in clearance of oxidized lipoproteins}

Another unique feature of LSECs is extraordinary endocytic activity. LSECs are rich in coated pits and vesicles and other organelles associated with endocytosis. Although LSEC constitute only $2.8 \%$ of the total liver volume, they contain about $15 \%$ of the total lysosomal volume and about $45 \%$ of the pinocytic vesicle volume of the liver (Blouin et 
al., 1977). Moreover, specific activities of several lysosomal enzymes are higher in LSECs than in other liver cells (Knook and Sleyster, 1980). LSECs express a set of high-affinity endocytic receptors for soluble macromolecular waste products, generated during normal tissue turnover, blood clotting, inflammatory processes and pathological conditions (McCourt et al., 1999; Skogh et al., 1985; Smedsrod, 2004; Smedsrod et al., 1994; Smedsrod et al., 2006; Smedsrod et al., 1997; Smedsrod et al., 1990). Connective tissue macromolecules including hyaluronan, chondroitin sulphate, collagen $\alpha$-chain, Procollagen Propeptides (PICP, PINP and PIIINP), products released during cell death such as lysosomal enzymes and metabolic byproducts including oxidized low density lipoproteins (oxLDLs), advanced glycation end products, and immune complexes and microbial CpG motifs are exclusively cleared from the blood circulation by mannose receptor-mediated or scavenger receptor-mediated endocytosis in LSECs (Elvevold et al., 2008; Malovic et al., 2007; Martin-Armas et al., 2006; Skogh et al., 1985; Smedsrod, 2004; Smedsrod et al., 1997; Smedsrod et al., 1990).

LSECs express several different scavenger receptors including scavenger receptors -A, scavenger receptors- $\mathrm{B}$, and scavenger receptors- $\mathrm{H}$ (Hughes et al., 1995; Malerod et al., 2002). However, stabilin-1 and stabilin-2 have been recognised as the main scavenger receptors on LSECs (Hansen et al., 2005; Hansen et al., 2002; McCourt et al., 1999; Politz et al., 2002; Zhou et al., 2000). Following receptor mediated endocytosis in LSECs most of the ligands are rapidly degraded intra-lysosomally. Thus, LSECs represent a major site of scavenging and degradation of harmful waste macromolecules from the circulation and have therefore been termed 'scavenger endothelial cells' (Seternes et al., 2002).

LSEC endocytosis of oxLDL may also be implicated in the development of atherosclerosis. Atherosclerosis begins as a progressive, chronic inflammatory condition characterized by thickening of the arterial intima through proliferation of intimal smooth muscle cells, which has been shown to be precipitated by cholesterol-rich LDL and triglycerides derived from chylomicron remnants (Fischer-Dzoga et al., 1976). This may then advance to a complex plaque, which can ultimately lead to serious cardiovascular complications, such as myocardial infarction and stroke from occluded arteries. The oxidative modification of LDL has been suggested to play an important role in the development of these events (Steinberg, 1997, 2009). LDL can undergo in vivo oxidation in the arterial walls (Yla-Herttuala et al., 1989) and in plasma (Avogaro et al., 1988; Holvoet et al., 1998b). The process starts within the LDL particle with oxidation of polyunsaturated fatty acids which generates a great number of various intermediate and end-products. Formation of free and organic radicals launches a chain reaction that causes fragmentation of both lipid and protein constituents of LDL. Formation of reactive aldehydes, such as malondialdehyde, 4-hydroxynonenal and glyoxal results in chemical modification of side chain amino groups of the lysine residues of apoB-100, which in turn leads to an increased net negative surface charge of the molecule (Baynes and Thorpe, 1999; Fu et al., 1996; Jialal and Devaraj, 1996; Oorni et al., 2000; Witztum and Steinberg, 1991; Young and McEneny, 2001). Therefore, the oxidative modification of LDL involves changes in both the protein and the lipid components of the LDL-particle. This in turn induces changes in surface charge and conformation, which renders LDL a ligand for scavenger receptors, and reduces or abolishes its affinity to the LDL receptor (Berliner and Heinecke, 1996; Li et al., 2011). 
In arterial intima, oxLDLs are taken up by macrophages via scavenger receptors. This induces foam cell formation and subsequent atheroma development (Henriksen et al., 1981, 1983; Steinbrecher et al., 1984). Oxldls are commonly present in atherosclerotic lesions of experimental animals and humans (Palinski et al., 1989; Yla-Herttuala et al., 1989). OxLDL has also been identified in plasma of healthy individuals (Avogaro et al., 1988; Ehara et al., 2001; Itabe and Takano, 2000). In patients with cardiovascular disease, plasma levels of oxLDL have been reported to be approximately fourfold higher than in healthy subjects (Ehara et al., 2001; Holvoet et al., 1998b). In addition to cardiovascular disease, increased levels of oxLDL are associated with ageing (Brinkley et al., 2009) and certain age-related pathologies, such as Alzheimer's disease (Kankaanpaa et al., 2009), glomerulosclerosis (Lee, 1999), and diabetes mellitus (Lopes-Virella et al., 1999).

Therefore, timely clearance and maintenance of low circulatory levels of oxLDLs appear to be important for the prevention of atherosclerosis (Holvoet et al., 1998b; Itabe, 2003). Previously, it has been shown that intravenously injected radiolabeled oxLDLs are rapidly removed from blood by uptake in Kupffer cells and LSECs (Ling et al., 1997; Van Berkel et al., 1991). However, a recent study demonstrated that Kupffer cells are only active in uptake of heavily oxidized LDL (Li et al., 2011). which is mainly present in atherosclerotic plaques (Yla-Herttuala et al., 1989) or formed as an artifact during in vitro oxLDL preparation. At the same time, LSECs hold an exclusive role in the uptake of mildly oxidized LDL from the circulation (Li et al., 2011). Mildly oxidized LDL is the major form of oxLDL found in the blood (Chang et al., 1997; Holvoet et al., 1998a; Holvoet et al., 1998b), and has proatherogenic properties (Berliner et al., 1990; Watson et al., 1997; Witztum and Steinberg, 1991). Both stabilin-1 and stabilin-2 are involved in the endocytic uptake of oxLDL by LSECs. Stabilin-1, however, appears to be more important for the uptake of mildly oxidized LDL, which represents physiological blood-borne oxLDL, while stabilin-2 is important for uptake when there is greater LDL modification (Li et al., 2011).

The morphological changes in the LSEC in old age might also affect its role in endocytosis. Recently, in vivo microscopy was used to examine the real time uptake of scavenger receptor ligands by LSECs (Ito et al., 2007). Endocytosis was clearly diminished in old mice, particularly in the pericentral zone which may indicate hypoxic liver damage. The effect of old age on clearance of oxLDL by LSEC has not been examined yet. However, involvement of stabilin 1 and 2, the two major LSEC scavenger receptors, in the process of oxLDL uptake (Li et al., 2011) makes it likely that oxLDL clearance would be diminished in old age. This change would increase the level of oxLDL in the circulation, thereby promoting its extrahepatic concentration and increasing the risk of the development of atherosclerosis.

\section{Conclusions}

Age-related changes in morphology and function of LSECs apparently contribute to dyslipidemia and, as a consequence, to the development of cardiovascular disease. Old age is associated with reduced fenestrae in the LSEC which impedes the hepatic uptake of chylomicron remnants and possibly other lipoproteins. In addition, aging is associated with reduced LSEC endocytic capacity which will impact on circulating levels of oxLDL. Thus the LSEC is a novel therapeutic target for the treatment of age-related dyslipidemia and has great potential for the prevention of atherosclerosis and cardiovascular events. 


\section{References}

Akinc, A., M. Goldberg, J. Qin, J. R. Dorkin, C. Gamba-Vitalo, M. Maier, K. N. Jayaprakash, M. Jayaraman, K. G. Rajeev, M. Manoharan, V. Koteliansky, I. Rohl, E. S. Leshchiner, R. Langer, and D. G. Anderson, 2009, Development of lipidoid-siRNA formulations for systemic delivery to the liver: Mol Ther, v. 17, p. 872-9.

Arias, I. M., 1990, The biology of hepatic endothelial cell fenestrae: Prog Liver Dis, v. 9, p. 1126.

Arii, S., and M. Imamura, 2000, Physiological role of sinusoidal endothelial cells and Kupffer cells and their implication in the pathogenesis of liver injury: J Hepatobiliary Pancreat Surg, v. 7, p. 40-8.

Aschoff, L., 1924, Das reticulo-endotheliale System: Ergebnisse inn. Med Kinderheilk, v. 26, p. 1-118.

Avogaro, P., G. B. Bon, and G. Cazzolato, 1988, Presence of a modified low density lipoprotein in humans: Arteriosclerosis, v. 8, p. 79-87.

Baker, R. W., 2004, Membrane Technology and Applications: Hokoben NJ, John Wiley \& Sons Ltd.

Baynes, J. W., and S. R. Thorpe, 1999, Role of oxidative stress in diabetic complications: a new perspective on an old paradigm: Diabetes, v. 48, p. 1-9.

Berliner, J. A., and J. W. Heinecke, 1996, The role of oxidized lipoproteins in atherogenesis: Free Radic Biol Med, v. 20, p. 707-27.

Berliner, J. A., M. C. Territo, A. Sevanian, S. Ramin, J. A. Kim, B. Bamshad, M. Esterson, and A. M. Fogelman, 1990, Minimally modified low density lipoprotein stimulates monocyte endothelial interactions: J Clin Invest, v. 85, p. 1260-6.

Blouin, A., R. P. Bolender, and E. R. Weibel, 1977, Distribution of organelles and membranes between hepatocytes and nonhepatocytes in the rat liver parenchyma. A stereological study: J Cell Biol, v. 72, p. 441-55.

Borel, P., N. Mekki, Y. Boirie, A. Partier, M. C. Alexandre-Gouabau, P. Grolier, and B. Beaufrere, 1998, Comparison of postprandial plasma vitamin A response in young and older adults: J Gerontol, v. 53, p. B133-140.

Brinkley, T. E., B. J. Nicklas, A. M. Kanaya, S. Satterfield, E. G. Lakatta, E. M. Simonsick, K. Sutton-Tyrrell, and S. B. Kritchevsky, 2009, Plasma oxidized low-density lipoprotein levels and arterial stiffness in older adults: the health, aging, and body composition study: Hypertension, v. 53, p. 846-52.

Chang, Y. H., D. S. Abdalla, and A. Sevanian, 1997, Characterization of cholesterol oxidation products formed by oxidative modification of low density lipoprotein: Free Radic Biol Med, v. 23, p. 202-14.

Cogger, V. C., and D. G. Le Couteur, 2009, Fenestrations in the liver sinusoidal endothelial cell, in I. Arias, A. Wolkoff, J. Boyer, D. Shafritz, N. Fausto, H. Alter, and A. Cohen, eds., The Liver: Biology and Pathobiology: Hokoben NJ, John Wiley \& Sons, Ltd, p. 387-404.

Cogger, V. C., A. Warren, R. Fraser, M. Ngu, A. J. McLean, and D. G. Le Couteur, 2003, Hepatic sinusoidal pseudocapillarization with aging in the non-human primate: Exp Gerontol, v. 38, p. 1101-1107. 
Cooper, A. D., 1997, Hepatic uptake of chylomicron remnants: J Lipid Res, v. 38, p. 217392.

Dietschy, J. M., S. D. Turley, and D. K. Spady, 1993, Role of liver in the maintenance of cholesterol and low density lipoprotein homeostasis in different animal species, including humans: J Lipid Res, v. 34, p. 1637-59.

Dobbs, B. R., G. W. Rogers, H. Y. Xing, and R. Fraser, 1994, Endotoxin-induced defenestration of the hepatic sinusoidal endothelium: a factor in the pathogenesis of cirrhosis?: Liver, v. 14, p. 230-3.

Ehara, S., M. Ueda, T. Naruko, K. Haze, A. Itoh, M. Otsuka, R. Komatsu, T. Matsuo, H. Itabe, T. Takano, Y. Tsukamoto, M. Yoshiyama, K. Takeuchi, J. Yoshikawa, and A. E. Becker, 2001, Elevated levels of oxidized low density lipoprotein show a positive relationship with the severity of acute coronary syndromes: Circulation, v. 103, p. 1955-60.

Elvevold, K., J. Simon-Santamaria, H. Hasvold, P. McCourt, B. Smedsrod, and K. K. Sorensen, 2008, Liver sinusoidal endothelial cells depend on mannose receptormediated recruitment of lysosomal enzymes for normal degradation capacity: Hepatology, v. 48, p. 2007-15.

Enzan, H., H. Himeno, M. Hiroi, H. Kiyoku, T. Saibara, and S. Onishi, 1997, Development of hepatic sinusoidal structure with special reference to the Ito cells: Microsc Res Tech, v. 39, p. 336-49.

Everitt, A., G. S. Roth, D. G. Le Couteur, and S. N. Hilmer, 2005, Calorie restriction versus drug therapy to delay the onset of aging diseases and extend life: Age, v. 27, p. 110.

Fischer-Dzoga, K., R. Fraser, and R. W. Wissler, 1976, Stimulation of proliferation in stationary primary cultures of monkey and rabbit aortic smooth muscle cells. I. Effects of lipoprotein fractions of hyperlipemic serum and lymph: Exp Mol Pathol, v. 24, p. 346-59.

Fraser, R., A. G. Bosanquet, and W. A. Day, 1978, Filtration of chylomicrons by the liver may influence cholesterol metabolism and atherosclerosis: Atherosclerosis, v. 29, p. 11323.

Fraser, R., L. M. Bowler, W. A. Day, B. Dobbs, H. D. Johnson, and D. Lee, 1980, High perfusion pressure damages the sieving ability of sinusoidal endothelium in rat livers: Br J Exp Pathol, v. 61, p. 222-8.

Fraser, R., W. J. Cliff, and F. C. Courtice, 1968, The effect of dietary fat load on the size and composition of chylomicrons in thoracic duct lymph: Q J Exp Physiol Cogn Med Sci, v. 53, p. 390-8.

Fraser, R., B. R. Dobbs, and G. W. Rogers, 1995, Lipoproteins and the liver sieve: the role of fenestrated sinusoidal endothelium in lipoprotein metabolism, atherosclerosis, and cirrhosis: Hepatology, v. 21, p. 863-874.

Fu, M. X., J. R. Requena, A. J. Jenkins, T. J. Lyons, J. W. Baynes, and S. R. Thorpe, 1996, The advanced glycation end product, Nepsilon-(carboxymethyl)lysine, is a product of both lipid peroxidation and glycoxidation reactions: J Biol Chem, v. 271, p. 9982-6. 
Fujioka, Y., and Y. Ishikawa, 2009, Remnant lipoproteins as strong key particles to atherogenesis: J Atheroscler Thromb, v. 16, p. 145-54.

Furrer, K., A. Rickenbacher, Y. Tian, W. Jochum, A. G. Bittermann, A. Kach, B. Humar, R. Graf, W. Moritz, and P. A. Clavien, Serotonin reverts age-related capillarization and failure of regeneration in the liver through a VEGF-dependent pathway: Proc Natl Acad Sci U S A, v. 108, p. 2945-50.

Hansen, B., P. Longati, K. Elvevold, G. I. Nedredal, K. Schledzewski, R. Olsen, M. Falkowski, J. Kzhyshkowska, F. Carlsson, S. Johansson, B. Smedsrod, S. Goerdt, and P. McCourt, 2005, Stabilin-1 and stabilin-2 are both directed into the early endocytic pathway in hepatic sinusoidal endothelium via interactions with clathrin/AP-2, independent of ligand binding: Exp Cell Res, v. 303, p. 160-73.

Hansen, B., D. Svistounov, R. Olsen, R. Nagai, S. Horiuchi, and B. Smedsrod, 2002, Advanced glycation end products impair the scavenger function of rat hepatic sinusoidal endothelial cells: Diabetologia, v. 45, p. 1379-88.

Henriksen, T., E. M. Mahoney, and D. Steinberg, 1981, Enhanced macrophage degradation of low density lipoprotein previously incubated with cultured endothelial cells: recognition by receptors for acetylated low density lipoproteins: Proc Natl Acad Sci US A, v. 78, p. 6499-503.

Henriksen, T., E. M. Mahoney, and D. Steinberg, 1983, Enhanced macrophage degradation of biologically modified low density lipoprotein: Arteriosclerosis, v. 3, p. 149-59.

Hilmer, S. N., V. C. Cogger, R. Fraser, A. J. McLean, D. Sullivan, and D. G. Le Couteur, 2005a, Age-related changes in the hepatic sinusoidal endothelium impede lipoprotein transfer in the rat: Hepatology, v. 42, p. 1349-54.

Hilmer, S. N., V. C. Cogger, R. Fraser, A. J. McLean, D. Sullivan, and D. G. Le Couteur, 2005b, Age-related changes in the hepatic sinusoidal endothelium impede lipoprotein transfer in the rat: Hepatology, v. 42, p. 1349-1354.

Holvoet, P., J. M. Stassen, J. Van Cleemput, D. Collen, and J. Vanhaecke, 1998a, Oxidized low density lipoproteins in patients with transplant-associated coronary artery disease: Arterioscler Thromb Vasc Biol, v. 18, p. 100-7.

Holvoet, P., J. Vanhaecke, S. Janssens, F. Van de Werf, and D. Collen, 1998b, Oxidized LDL and malondialdehyde-modified LDL in patients with acute coronary syndromes and stable coronary artery disease: Circulation, v. 98, p. 1487-94.

Hughes, D. A., I. P. Fraser, and S. Gordon, 1995, Murine macrophage scavenger receptor: in vivo expression and function as receptor for macrophage adhesion in lymphoid and non-lymphoid organs: Eur J Immunol, v. 25, p. 466-73.

Itabe, H., 2003, Oxidized low-density lipoproteins: what is understood and what remains to be clarified: Biol Pharm Bull, v. 26, p. 1-9.

Itabe, H., and T. Takano, 2000, Oxidized low density lipoprotein: the occurrence and metabolism in circulation and in foam cells: J Atheroscler Thromb, v. 7, p. 12331.

Ito, Y., K. K. Sorensen, N. W. Bethea, D. Svistounov, M. K. McCuskey, B. H. Smedsrod, and R. S. McCuskey, 2007, Age-related changes in the hepatic microcirculation of mice: Exp Gerontol, v. 48, p. 789-797. 
Jamieson, H., S. N. Hilmer, V. C. Cogger, A. Warren, R. Cheluvappa, D. R. Abernethy, A. Everitt, R. Fraser, R. de Cabo, and D. G. Le Couteur, 2007, Caloric restriction reduces age-related pseudocapillarization of the hepatic sinusoid: Experimental Gerontology, v. 42, p. 374-8.

Jialal, I., and S. Devaraj, 1996, Low-density lipoprotein oxidation, antioxidants, and atherosclerosis: a clinical biochemistry perspective: Clin Chem, v. 42, p. 498506.

Kankaanpaa, J., S. P. Turunen, V. Moilanen, S. Horkko, and A. M. Remes, 2009, Cerebrospinal fluid antibodies to oxidized LDL are increased in Alzheimer's disease: Neurobiol Dis, v. 33, p. 467-72.

Karpe, F., G. Steiner, K. Uffelman, T. Olivecrona, and A. Hamsten, 1994, Postprandial lipoproteins and progression of coronary atherosclerosis: Atherosclerosis, v. 106, p. 83-97.

Kawai, Y., B. Smedsrod, K. Elvevold, and K. Wake, 1998, Uptake of lithium carmine by sinusoidal endothelial and Kupffer cells of the rat liver: new insights into the classical vital staining and the reticulo-endothelial system: Cell Tissue Res, v. 292, p. 395-410.

Knook, D. L., and E. C. Sleyster, 1976, Separation of Kupffer and endothelial cells of the rat liver by centrifugal elutriation: Exp Cell Res, v. 99, p. 444-9.

Knook, D. L., and E. C. Sleyster, 1980, Isolated parenchymal, Kupffer and endothelial rat liver cells characterized by their lysosomal enzyme content: Biochem Biophys Res Commun, v. 96, p. 250-7.

Krasinski, S. D., J. S. Cohn, E. J. Schaefer, and R. M. Russell, 1990, Postprandial plasma retinyl ester response is greater in older subjects compared with younger subjects. Evidence for delayed plasma clearance of intestinal lipoproteins: J Clin Invest, v. 85, p. 883-892.

Lakatta, E. G., and D. Levy, 2003, Arterial and cardiac aging: major shareholders in cardiovascular disease enterprises: Part I: aging arteries: a "set up" for vascular disease: Circulation, v. 107, p. 139-146.

Le Couteur, D. G., V. C. Cogger, S. N. Hilmer, M. Muller, M. Harris, D. Sullivan, A. J. McLean, and R. Fraser, 2006, Aging, atherosclerosis and the liver sieve, in L. V. Clark, ed., New Research on Atherosclerosis: NY, Nova Science, p. 19-44.

Le Couteur, D. G., V. C. Cogger, A. M. A. Markus, P. J. Harvey, Z. L. Yin, A. D. Ansselin, and A. J. McLean, 2001, Pseudocapillarization and associated energy limitation in the aged rat liver: Hepatology, v. 33, p. 537-543.

Le Couteur, D. G., R. Fraser, V. C. Cogger, and A. J. McLean, 2002, Hepatic pseudocapillarisation and atherosclerosis in ageing: Lancet, v. 359, p. 1612-1615.

Le Couteur, D. G., R. Fraser, S. Hilmer, L. P. Rivory, and A. J. McLean, 2005, The hepatic sinusoid in aging and cirrhosis - Effects on hepatic substrate disposition and drug clearance: Clin Pharmacokinet, v. 44, p. 187-200.

Le Couteur, D. G., and A. J. McLean, 1998, The aging liver - Drug clearance and an oxygen diffusion barrier hypothesis: Clin Pharmacokinet, v. 34, p. 359-373. 
Le Couteur, D. G., A. Warren, V. C. Cogger, B. Smedsrod, K. K. Sorensen, R. De Cabo, R. Fraser, and R. S. McCuskey, 2008, Old age and the hepatic sinusoid: Anat Rec (Hoboken), v. 291, p. 672-83.

Lee, H. S., 1999, Oxidized LDL, glomerular mesangial cells and collagen: Diabetes Res Clin Pract, v. 45, p. 117-22.

Li, R., A. Oteiza, K. K. Sorensen, P. McCourt, R. Olsen, B. Smedsrod, and D. Svistounov, 2011, Role of liver sinusoidal endothelial cells and stabilins in elimination of oxidized low-density lipoproteins: Am J Physiol Gastrointest Liver Physiol, v. 300, p. G71-81.

Lin, Y., S. S. Mousa, N. Elshourbagy, and S. A. Mousa, Current status and future directions in lipid management: emphasizing low-density lipoproteins, high-density lipoproteins, and triglycerides as targets for therapy: Vasc Health Risk Manag, v. 6, p. 73-85.

Ling, W., M. Lougheed, H. Suzuki, A. Buchan, T. Kodama, and U. P. Steinbrecher, 1997, Oxidized or acetylated low density lipoproteins are rapidly cleared by the liver in mice with disruption of the scavenger receptor class A type I/II gene: J Clin Invest, v. 100, p. 244-52.

Lopes-Virella, M. F., G. Virella, T. J. Orchard, S. Koskinen, R. W. Evans, D. J. Becker, and K. Y. Forrest, 1999, Antibodies to oxidized LDL and LDL-containing immune complexes as risk factors for coronary artery disease in diabetes mellitus: Clin Immunol, v. 90, p. 165-72.

Malerod, L., K. Juvet, T. Gjoen, and T. Berg, 2002, The expression of scavenger receptor class B, type I (SR-BI) and caveolin-1 in parenchymal and nonparenchymal liver cells: Cell Tissue Res, v. 307, p. 173-80.

Malovic, I., K. K. Sorensen, K. H. Elvevold, G. I. Nedredal, S. Paulsen, A. V. Erofeev, B. H. Smedsrod, and P. A. McCourt, 2007, The mannose receptor on murine liver sinusoidal endothelial cells is the main denatured collagen clearance receptor: Hepatology, v. 45, p. 1454-61.

Martin-Armas, M., J. Simon-Santamaria, I. Pettersen, U. Moens, B. Smedsrod, and B. Sveinbjornsson, 2006, Toll-like receptor 9 (TLR9) is present in murine liver sinusoidal endothelial cells (LSECs) and mediates the effect of CpGoligonucleotides: J Hepatol, v. 44, p. 939-46.

Martinez-Hernandez, A., and P. S. Amenta, 1993, The hepatic extracellular matrix. I. Components and distribution in normal liver: Virchows Arch A Pathol Anat Histopathol, v. 423, p. 1-11.

McCourt, P. A., B. H. Smedsrod, J. Melkko, and S. Johansson, 1999, Characterization of a hyaluronan receptor on rat sinusoidal liver endothelial cells and its functional relationship to scavenger receptors: Hepatology, v. 30, p. 1276-86.

McLean, A. J., V. C. Cogger, G. C. Chong, A. Warren, A. M. Markus, J. E. Dahlstrom, and D. G. Le Couteur, 2003, Age-related pseudocapillarization of the human liver: J Pathol, v. 200, p. 112-117.

McLean, A. J., and D. G. Le Couteur, 2004, Aging biology and geriatric clinical pharmacology: Pharmacol Rev, v. 56, p. 163-184. 
Naito, M., and E. Wisse, 1978, Filtration effect of endothelial fenestrations on chylomicron transport in neonatal rat liver sinusoids: Cell Tissue Res, v. 190, p. 371-82.

Nonaka, H., M. Tanaka, K. Suzuki, and A. Miyajima, 2007, Development of murine hepatic sinusoidal endothelial cells characterized by the expression of hyaluronan receptors: Dev Dyn, v. 236, p. 2258-67.

O'Reilly, J. N., V. C. Cogger, R. Fraser, and D. G. Le Couteur, 2010, The effect of feeding and fasting on fenestrations in the liver sinusoidal endothelial cell: Pathology, v. 42, p. 255-8.

O'Reilly, J. N., V. C. Cogger, and D. G. Le Couteur, 2009, Old age is associated with ultrastructural changes in isolated rat liver sinusoidal endothelial cells: J Electron Microsc (Tokyo).

Oorni, K., M. O. Pentikainen, M. Ala-Korpela, and P. T. Kovanen, 2000, Aggregation, fusion, and vesicle formation of modified low density lipoprotein particles: molecular mechanisms and effects on matrix interactions: J Lipid Res, v. 41, p. 1703-14.

Palinski, W., M. E. Rosenfeld, S. Yla-Herttuala, G. C. Gurtner, S. S. Socher, S. W. Butler, S. Parthasarathy, T. E. Carew, D. Steinberg, and J. L. Witztum, 1989, Low density lipoprotein undergoes oxidative modification in vivo: Proc Natl Acad Sci U S A, v. 86, p. 1372-6.

Politz, O., A. Gratchev, P. A. McCourt, K. Schledzewski, P. Guillot, S. Johansson, G. Svineng, P. Franke, C. Kannicht, J. Kzhyshkowska, P. Longati, F. W. Velten, and S. Goerdt, 2002, Stabilin-1 and -2 constitute a novel family of fasciclin-like hyaluronan receptor homologues: Biochem J, v. 362, p. 155-64.

Popper, H., 1986, Aging and the liver: Prog Liver Dis, v. VIII, p. 659-683.

Schmucker, D. L., 1998, Aging and the liver: an update: J Gerontol, v. 53A, p. B315-B320.

Seternes, T., K. Sorensen, and B. Smedsrod, 2002, Scavenger endothelial cells of vertebrates: a nonperipheral leukocyte system for high-capacity elimination of waste macromolecules: Proc Natl Acad Sci U S A, v. 99, p. 7594-7.

Simons, L. A., J. Simons, Y. Friedlander, and J. McCallum, 2001, Cholesterol and other lipids predict coronary heart disease and ischemic stroke in the elderly, but only in those below 70 years: Atherosclerosis, v. 159, p. 201-208.

Skogh, T., R. Blomhoff, W. Eskild, and T. Berg, 1985, Hepatic uptake of circulating IgG immune complexes: Immunology, v. 55, p. 585-94.

Smedsrod, B., 2004, Clearance function of scavenger endothelial cells: Comp Hepatol, v. 3 Suppl 1, p. S22.

Smedsrod, B., P. J. De Bleser, F. Braet, P. Lovisetti, K. Vanderkerken, E. Wisse, and A. Geerts, 1994, Cell biology of liver endothelial and Kupffer cells: Gut, v. 35, p. 1509-16.

Smedsrod, B., K. Elvevold, and I. Martinez, 2006, The liver sinusoidal endothelial cell: a cell type of controversial and confusing identity: 13th International Symposium on Cells of the Hepatic Sinusoid, v. 13th, p. 61-62.

Smedsrod, B., D. Le Couteur, K. Ikejima, H. Jaeschke, N. Kawada, M. Naito, P. Knolle, L. Nagy, H. Senoo, F. Vidal-Vanaclocha, and N. Yamaguchi, 2009, Hepatic sinusoidal cells in health and disease: Liver Int, v. 29, p. 490-501. 
Smedsrod, B., J. Melkko, N. Araki, H. Sano, and S. Horiuchi, 1997, Advanced glycation end products are eliminated by scavenger-receptor-mediated endocytosis in hepatic sinusoidal Kupffer and endothelial cells: Biochem J, v. 322 ( Pt 2), p. 567-73.

Smedsrod, B., H. Pertoft, S. Gustafson, and T. C. Laurent, 1990, Scavenger functions of the liver endothelial cell: Biochem J, v. 266, p. 313-27.

Stacchiotti, A., A. Lavazza, M. Ferroni, G. Sberveglieri, R. Bianchi, R. Rezzani, and L. F. Rodella, 2008, Effects of aluminium sulphate in the mouse liver: similarities to the aging process: Exp Gerontol, v. 43, p. 330-8.

Steinberg, D., 1997, Low density lipoprotein oxidation and its pathobiological significance: J Biol Chem, v. 272, p. 20963-6.

Steinberg, D., 2009, The LDL modification hypothesis of atherogenesis: an update: J Lipid Res, v. 50 Suppl, p. S376-81.

Steinbrecher, U. P., S. Parthasarathy, D. S. Leake, J. L. Witztum, and D. Steinberg, 1984, Modification of low density lipoprotein by endothelial cells involves lipid peroxidation and degradation of low density lipoprotein phospholipids: Proc Natl Acad Sci U S A, v. 81, p. 3883-7.

Van Berkel, T. J., Y. B. De Rijke, and J. K. Kruijt, 1991, Different fate in vivo of oxidatively modified low density lipoprotein and acetylated low density lipoprotein in rats. Recognition by various scavenger receptors on Kupffer and endothelial liver cells: J Biol Chem, v. 266, p. 2282-9.

Vidal-Vanaclocha, F., and E. Barbera-Guillem, 1985, Fenestration patterns in endothelial cells of rat liver sinusoids: J Ultrastruct Res, v. 90, p. 115-23.

Warren, A., P. Bertolino, V. C. Cogger, A. J. McLean, R. Fraser, and D. G. Le Couteur, 2005, Hepatic pseudocapillarization in aged mice: Exp Gerontol, v. 40, p. 807-12.

Watson, A. D., N. Leitinger, M. Navab, K. F. Faull, S. Horkko, J. L. Witztum, W. Palinski, D. Schwenke, R. G. Salomon, W. Sha, G. Subbanagounder, A. M. Fogelman, and J. A. Berliner, 1997, Structural identification by mass spectrometry of oxidized phospholipids in minimally oxidized low density lipoprotein that induce monocyte/endothelial interactions and evidence for their presence in vivo: J Biol Chem, v. 272, p. 13597-607.

Watson, K. E., B. N. Horowitz, and G. Matson, 2003, Lipid abnormalities in insulin resistant states: Rev Cardiovasc Med, v. 4, p. 228-36.

Williams, K. J., 2008, Molecular processes that handle -- and mishandle -- dietary lipids: J Clin Invest, v. 118, p. 3247-59.

Wisse, E., 1970, An electron microscopic study of the fenestrated endothelial lining of rat liver sinusoids: J Ultrastruct Res, v. 31, p. 125-50.

Wisse, E., F. Braet, D. Luo, R. De Zanger, D. Jans, E. Crabbe, and A. Vermoesen, 1996, Structure and function of sinusoidal lining cells in the liver: Toxicol Pathol, v. 24, p. 100-11.

Witztum, J. L., and D. Steinberg, 1991, Role of oxidized low density lipoprotein in atherogenesis: J Clin Invest, v. 88, p. 1785-92.

Yla-Herttuala, S., W. Palinski, M. E. Rosenfeld, S. Parthasarathy, T. E. Carew, S. Butler, J. L. Witztum, and D. Steinberg, 1989, Evidence for the presence of oxidatively modified low density lipoprotein in atherosclerotic lesions of rabbit and man: J Clin Invest, v. 84 , p. $1086-95$. 
Young, I. S., and J. McEneny, 2001, Lipoprotein oxidation and atherosclerosis: Biochem Soc Trans, v. 29, p. 358-62.

Zhou, B., J. A. Weigel, L. Fauss, and P. H. Weigel, 2000, Identification of the hyaluronan receptor for endocytosis (HARE): J Biol Chem, v. 275, p. 37733-41. 


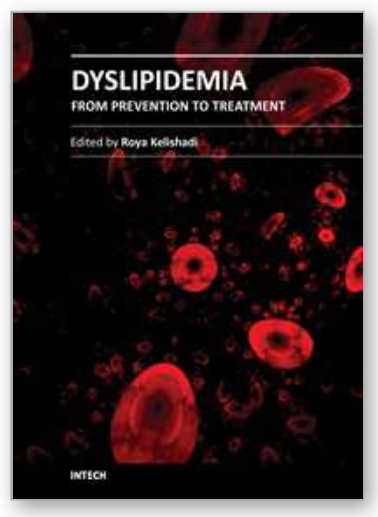

\author{
Dyslipidemia - From Prevention to Treatment \\ Edited by Prof. Roya Kelishadi
}

ISBN 978-953-307-904-2

Hard cover, 468 pages

Publisher InTech

Published online 03, February, 2012

Published in print edition February, 2012

Dyslipidemia has a complex pathophysiology consisting of various genetic, lifestyle, and environmental factors. It has many adverse health impacts, notably in the development of chronic non-communicable diseases.

Significant ethnic differences exist due to the prevalence and types of lipid disorders. While elevated serum total- and LDL-cholesterol are the main concern in Western populations, in other countries hypertriglyceridemia and low HDL-cholesterol are more prevalent. The latter types of lipid disorders are considered as components of the metabolic syndrome. The escalating trend of obesity, as well as changes in lifestyle and environmental factors will make dyslipidemia a global medical and public health threat, not only for adults but for the pediatric age group as well. Several experimental and clinical studies are still being conducted regarding the underlying mechanisms and treatment of dyslipidemia. The current book is providing a general overview of dyslipidemia from diverse aspects of pathophysiology, ethnic differences, prevention, health hazards, and treatment.

\title{
How to reference
}

In order to correctly reference this scholarly work, feel free to copy and paste the following:

Dmitri Svistounov, Svetlana N. Zykova, Victoria C. Cogger, Alessandra Warren, Aisling C. McMahon, Robin Fraser and David G. Le Couteur (2012). Liver Sinusoidal Endothelial Cells and Regulation of Blood Lipoproteins, Dyslipidemia - From Prevention to Treatment, Prof. Roya Kelishadi (Ed.), ISBN: 978-953-307904-2, InTech, Available from: http://www.intechopen.com/books/dyslipidemia-from-prevention-totreatment/liver-sinusoidal-endothelial-cells-and-regulation-of-blood-lipoproteins

\section{INTECH}

open science | open minds

\section{InTech Europe}

University Campus STeP Ri

Slavka Krautzeka 83/A

51000 Rijeka, Croatia

Phone: +385 (51) 770447

Fax: +385 (51) 686166

www.intechopen.com

\section{InTech China}

Unit 405, Office Block, Hotel Equatorial Shanghai

No.65, Yan An Road (West), Shanghai, 200040, China 中国上海市延安西路65号上海国际贵都大饭店办公楼 405 单元

Phone: +86-21-62489820

Fax: $+86-21-62489821$ 
(C) 2012 The Author(s). Licensee IntechOpen. This is an open access article distributed under the terms of the Creative Commons Attribution 3.0 License, which permits unrestricted use, distribution, and reproduction in any medium, provided the original work is properly cited. 